\title{
SITE SUITABILITY ANALYSIS FOR GROWING SHORT DURATION CROPS IN POST KHARIF RICE-RABI FALLOWS: AN EXPLORATORY STUDY FOR FOUR DISTRICTS OF EASTERN INDIA
}

\author{
Meghavi Prashnani ${ }^{1 *}$, Shalini Saxena ${ }^{1}, K_{a r u n}$ Chaudhary ${ }^{2}$, C. S. Murthy ${ }^{2}$ and S. S. Ray ${ }^{1}$ - meghavi@umd.edu, shalini.85@gov.in, \\ (karunkumar_choudhary, murthy_cs)@nrsc.gov.in, shibendu.ncfc@nic.in
}

${ }^{1}$ Mahalanobis National Crop Forecast Centre, (DAC\&FW) New Delhi-110012, India

${ }^{2}$ National Remote Sensing Centre, ISRO, Hyderabad, India

\section{Commission III, WG III/10}

KEY WORDS: Kharif Rice, fallow land, Site suitability, PASM, RISAT-1, Resourcesat-2

\begin{abstract}
:
India is one of the leading rice producing countries in the world. In eastern part of the country, after harvesting of kharif rice crops, large area remains fallow, mostly due to unavailability of irrigation facility. Approximately 30 percent of total kharif rice area (i.e. around $12 \mathrm{Mha}$ ) is left fallow during rabi season. Government of India, in order to improve the land productivity, cropping intensity and food security, has taken up various initiatives to grow pulses in these areas. A project was launched under the National Food Security Mission for use of satellite remote sensing for suitability analysis towards crop intensification in 6 eastern Indian states. Before execution of the project an exploratory study was carried out for 4 selected districts of 2 major rice-fallow states of the country. The selected districts were Raipur and Surguja districts of Chhattisgarh state and Mayurbhanj and Balasore districts of Odisha state. Kharif rice area was mapped using RISAT-1 SAR data, while rabi fallow area was mapped using Resourcesat- 2 AWiFS and Landsat-8 OLI data. Suitable area for growing pulses were analysed with respect to various soil, weather and land parameters such as, mean monthly air temperature $\left({ }^{\circ} \mathrm{C}\right)$, Slope $(\%)$, Surface wetness, Plant available water capacity $(\mathrm{mm})$ and proximity to drainage network. The post kharif rice-rabi fallow area, in these districts ranged between $20-40 \%$ of the geographical area, while the suitable area was found to be in range of between $8-12 \%$. Thus, this exploratory study could show, with remote sensing and other agro-physical parameters, it is possibly not only to map the rice-fallow area, but also to assess the suitability of growing short duration rabi crops.
\end{abstract}

\section{INTRODUCTION}

In large part of eastern India, areas where the kharif season (June-October) rainfed rice and/or irrigated rice crops are grown often remain fallow during the rabi season (NovemberFebruary). This is mainly because these lands do not have sufficient water to grow important staple crops (e.g. rice, wheat) during rabi season. There is however the opportunity to grow water-efficient short-season grain legumes, which have a high market demand and improve soil health via nitrogen fixation (Dabin 2016, Dixon 2007, Ghosh 2007). These cropland areas are not suitable for growing rabi-season rice due to their highwater needs, but are suitable for a short -season ( $\leq 3$ months), low water-consuming grain legumes such as chickpea, black gram, green gram and lentils. Intensification (double-cropping) in this manner can improve smallholder farmer's incomes and soil health via rich nitrogen-fixation legume crops as well as address food security challenges of increasing populations without having to expand croplands.

Considering the importance of rice fallow areas for increasing food grain production, there have been many studies for understanding the suitability of rice fallow areas for growing rabi season pulses. Study shows highest rice-fallow area in Chhattisgarh, followed by Bihar (including Jharkhand), West Bengal and Odisha. It is estimated that 6.7 million hectares of potentially productive lands throughout the eastern IGP remain underutilized and fallow following the summer or kharif rice crop (Subbarao, 2001).

*Corresponding Author, current address: Univ. of Maryland, USA,

\begin{tabular}{|c|c|c|c|c|c|c|c|c|}
\hline State & $\begin{array}{l}\text { Geog } \\
\text { Area }\end{array}$ & $\begin{array}{l}\text { Net } \\
\text { Sown } \\
\text { Area }\end{array}$ & $\begin{array}{l}\text { Gross } \\
\text { Cropped } \\
\text { Area }\end{array}$ & $\begin{array}{l}\text { Cropping } \\
\text { Intensity } \\
(\%)\end{array}$ & $\begin{array}{l}\text { Kharif } \\
\text { Rice } \\
\text { Area }\end{array}$ & $\begin{array}{l}\text { Rabi } \\
\text { Food } \\
\text { Grain } \\
\text { Area }\end{array}$ & $\begin{array}{l}\text { Rabi } \\
\text { Oilseed } \\
\text { sArea }\end{array}$ & $\begin{array}{l}(\mathrm{G}+\mathrm{H}) / \\
\mathrm{F}\end{array}$ \\
\hline $\mathrm{A}$ & B & $\mathrm{C}$ & D & E & $\mathrm{F}$ & G & $\mathrm{H}$ & I \\
\hline Assam & 7844 & 2820 & 4100 & 145.4 & 2050.0 & 574.4 & 74.3 & 0.316 \\
\hline Bihar & 9416 & 5252 & 7580 & 144.3 & 3038.6 & 3010.3 & 111.2 & 1.027 \\
\hline Chhattisgarh & 13519 & 4686 & 5698 & 121.6 & 3802.1 & 745.5 & 1.1 & 0.196 \\
\hline Jharkhand & 7972 & 1384 & 1672 & 120.8 & 1255.9 & 415.6 & -. & 0.331 \\
\hline Odisha & 15571 & 4495 & 5168 & 115.0 & 3879.7 & 627.6 & 14.7 & 0.166 \\
\hline West Bengal & 8875 & 5234 & 9618 & 183.8 & 4226.7 & 1889.6 & 574.8 & 0.583 \\
\hline
\end{tabular}

Table 1. Land Use and Crop statistics of selected States for 2013-14

A ratio of rabi food grain and oilseeds area with kharif rice area shows Odisha has lowest ratio, followed by Chhattisgarh, indicates these two states have high post kharif rice fallow area (Table 1). An estimate by National Mission on Oilseeds and Oil Palm (NMOOP) shows that, among these six states Odisha has highest area of rice fallows (2.961 $\mathrm{MHa})$, followed by Chhattisgarh (2.856 MHa), West Bengal (1.159 MHa), Assam (1.042 MHa), Jharkhand (0.475 MHa) and Bihar (0.049 MHa). The main reasons for 'rice fallows' include [Chandna, 2004].

- Unavailability of irrigation water for preparatory tillage in many uplands, mid-lands and diara lands Excessive soil moisture precludes preparatory tillage for planting of winter season crops; 
$\bullet$

Floodwaters recede late in the winter crop season from tal lands;

$\bullet$

Runoff water not vacating fields (water logging) in chaur lands; and

- $\quad$ Excessive presence of aquatic weeds.

Pulses enrich soils by fixing nitrogen and also increase soil microbe diversity. The leaf droppings provide green manure and in severely eroded soils these crops help conserve top soil and rejuvenate degraded land. This study estimated the land suitability for pulses or short duration crops that can be planted in fallow lands after kharif rice harvesting in study districts using remote sensing and GIS technology and field survey. So that fallow lands can be utilized for the legume crops which will improve the soil health by fixing nitrogen into the soil which will help to increase the productivity of crop for next season.

\section{STUDY AREA}

This study covers four districts, namely Balasore \& Mayurbhanj in Odisha and Raipur \& Surguja in Chhattisgarh (Figure 1). These districts are selected on the basis of district-wise statistics of kharif rice and post kharif rice rabi fallow land use statistics generated using kharif maps and rabi fallow maps.

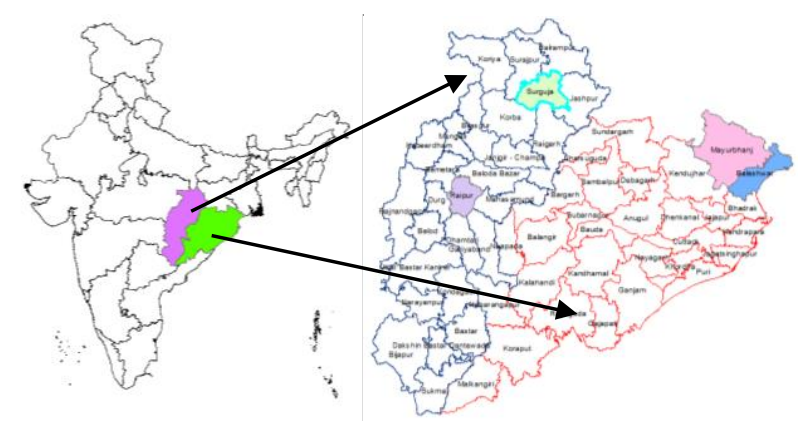

Figure 1: Study area

\section{METHODOLOGY}

Rabi fallow was mapped using multidate AWiFS (56 m resolution) and Lansat-8 OLI (30 m resolution) optical satellite data. Kharif rice maps were generated under FASAL project of MNCFC using RISAT-1 SAR MRS data (25 m resolution). These Kharif maps were intersected with rabi fallow area maps to generate post Kharif rice - rabi fallow areas.

Kharif rice layer for year 2015-16 were generated using three date RISAT-1 (C-band SAR) MRS mode data. In this study satellite data were used based upon the crop calendar of individual states. The SAR data has been taken from mid-June to September. Logical modeling classification approach was used and further verification was carried out using ground truth points overlaid on images. Based upon the backscatter value and the phenological growth of paddy, the classification algorithm was developed. All these works were carried out under FASAL project. For suitability analysis other indices such as LSWI (Land Surface wetness Index), which is an indicator of vegetation and soil water content were generated using Landsat8 OLI data. Other data used in the study are given below.
- Plant Available Water Capacity (AWC) data generated through 1:250000 scale or 1:50000 scale maps; slope using SRTM DEM (30 m)

- Weather data: Temperature in January month of rabi season

- $\quad$ Land Surface Wetness index (LSWI) for rabi season

- $\quad$ Other data - Drainage network

Ground truth (field information) is an essential component, not only for forming criteria/models for crop classification, but also for accuracy verification of crop mapping. The GT data were collected by making field visits or with the support of the State Agriculture Department officials under FASAL project.

Multi-criteria approach was used to generate suitability map to grow short-duration crops in post-kharif rice fallows (Figure 2.). The threshold limits has been set to test the suitability of land for growing short duration rabi season crops or oilseed \& pulses. For LSWI, the criteria fixed (equals to and more than 0.1 ), Mean monthly air temp $>18^{\circ} \mathrm{C} \leq 24^{\circ} \mathrm{C}$ and Plant Available Water Content is more than $75 \%$. This criteria was applied to the post kharif rice and rabi fallow classes to identify the suitable lands for pulse cropping.

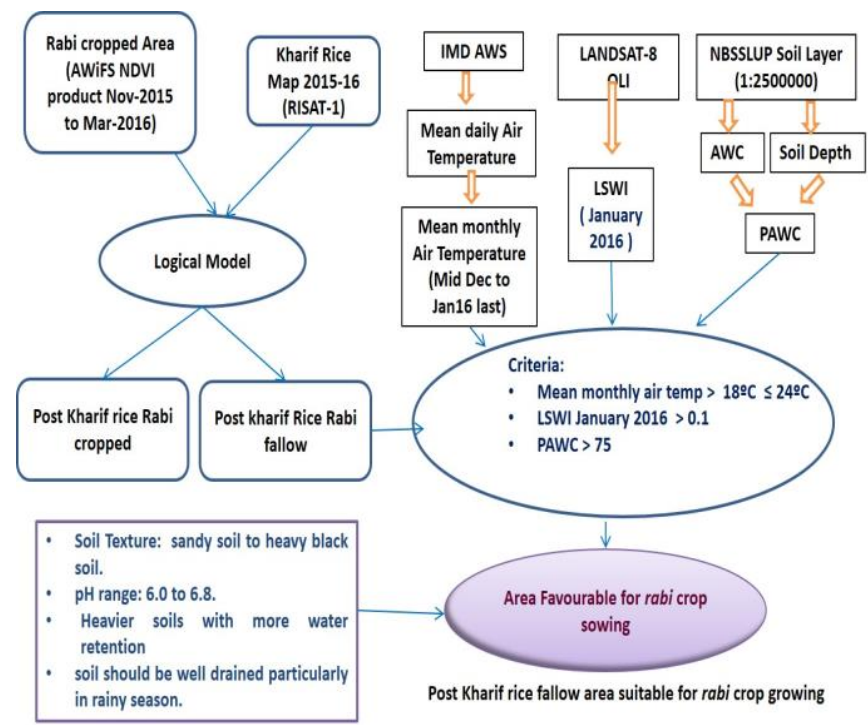

Figure 2: Methodology for post kharif-rice fallow area mapping and their suitability analysis.

\section{RESULTS AND DISCUSSIONS}

\subsection{Crop area statistics and Site suitability analysis for Raipur (Chhattisgarh)}

In Raipur district (Chhattisgarh), total kharif rice area and rabi cropped area is found to be $48.3 \%, 26.7 \%$ respectively. Land suitable for short duration rabi crops is found to be $12.5 \%$, which is $38 \%$ of post kharif rice - rabi fallow area. Figure 3 is showing the maps of Average temperature, PAWC, LSWI, Kharif rice, post kharif rice and rabi fallow and suitable area for Raipur district, Chhattisgarh. Arang block is showing large suitable area than Abhanpur, Raipur and Tilda blocks. A large area remains Fallow (40.9\%) in Tilda block (Figure 4). 


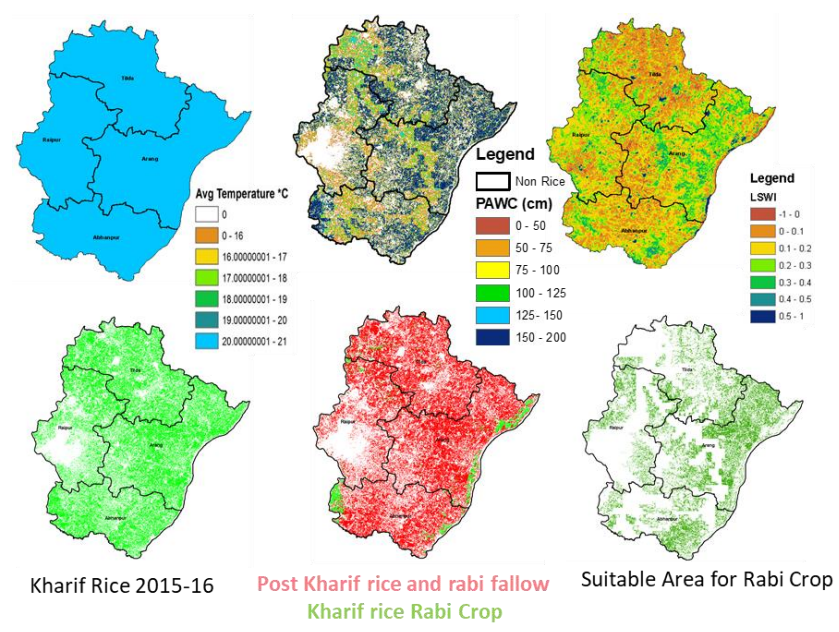

Figure 3: Block wise maps of Average temperature, PAWC, LSWI, Kharif rice, post kharif rice and rabi fallow and suitable area for Raipur district, Chhattisgarh

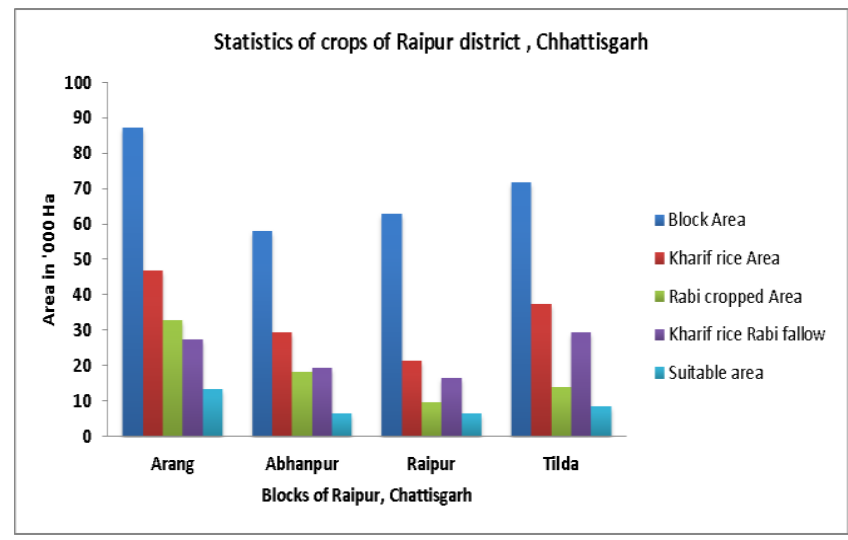

Figure 4: Block wise statistics in Raipur district, Chhattisgarh

\subsection{Crop area statistics and Site suitability analysis for Surguja (Chhattisgarh)}

In Surguja district (Chhattisgarh) $29.9 \%$ area is found to be under kharif rice and $8.2 \%$ area under rabi seasons crops and land suitable for short duration rabi crop is $8.7 \%$. This is $32 \%$ of post kharif rice rabi fallow lands. Figure 5 is showing the maps of Average temperature, PAWC, LSWI, Kharif rice, post kharif rice and rabi fallow and suitable area for Surguja district, Chhattisgarh. Sitapur block is showing highest suitability for rabi crops sowing (Figure 6). Lundra block is showing least percentage of suitable land for growing short duration crop in rabi season.

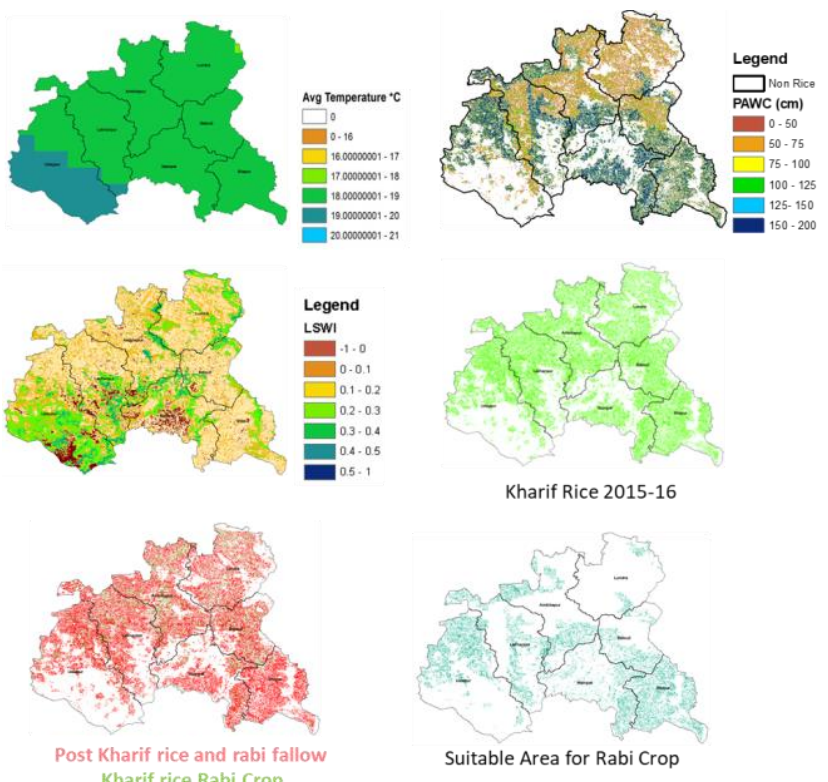

Figure 6: Block wise maps of Average temperature, PAWC, LSWI, Kharif rice mask, post kharif rice and rabi fallow and suitable area for Sarguja , Chhattisgarh

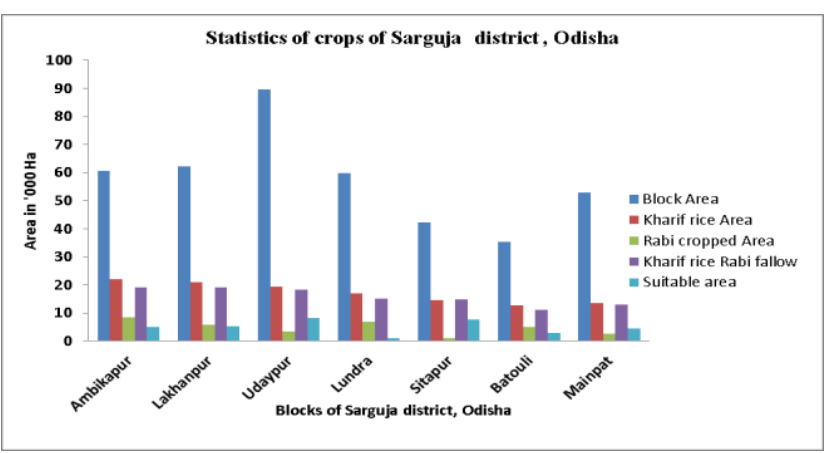

Figure 5. Block wise statistics in Sarguja district, Chhattisgarh

\subsection{Site suitability analysis for Mayurbhanj (Odisha)}

Mayurbhanj district consists of 26 tehsils and 26 blocks. Net Sown Area is $419902 \mathrm{Ha}$, Gross cropped Area is $562733 \mathrm{Ha}$ and Average Cropping Intensity is $74.8 \%$.

$24.1 \%$ area is found under kharif rice out of total area in Mayurbhanj district and $10.1 \%$ area under rabi crops out of total area. So, the total percentage of area is 20.3 under fallow lands in rabi season after kharif rice harvesting and $3.8 \%$ area covered under rabi crops after kharif harvesting (Figure 7). A total of $8.2 \%$ area is found to be suitable for short duration rabi crop. $45.4 \%$ lands found fallow in rabi seasons in Gopbandhunagar and $42.5 \%$ in Betanati. Saraskana block is less suitable for short duration rabi cropping (Figure 8), whereas Surukuli block is found more suitable (15.5\%) among all blocks. 


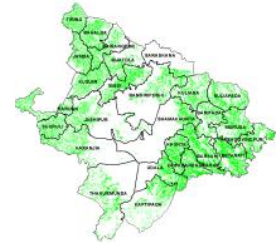

Kharif Rice 2015-16

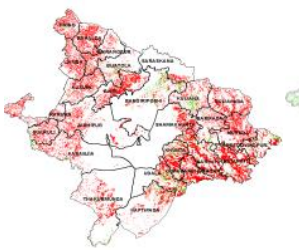

Post Kharif rice and rabi fallow Kharif rice Rabi Crop

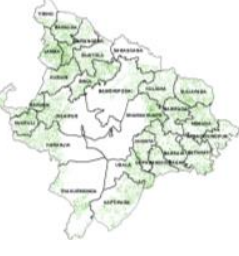

Suitable Area for rabi Crop

(n)

Figure 7. Block wise Kharif rice, post kharif rice and rabi fallow and suitable area for Mayurbhanj district, Odisha

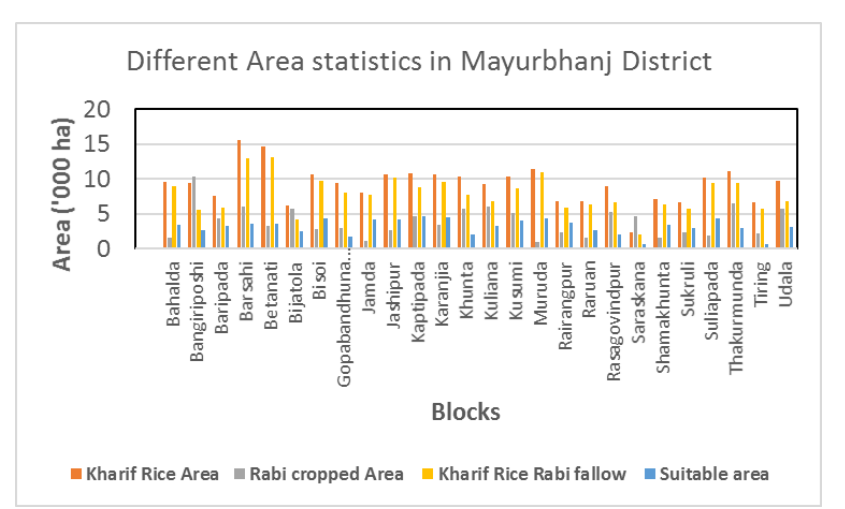

Figure 8: Block level Statistics of Mayurbhanj district of Odisha

\subsection{Site suitability analysis for Balasore (Odisha)}

Balasore District Consist of 12 Blocks, with Net Sown Area: $250550 \mathrm{Ha}$, Gross cropped Area is $352839 \mathrm{Ha}$ and Cropping Intensity is $140.83 \%$. (DIP, 2016).

$55.1 \%$ area is found under kharif rice out of total area in Balasore district and 29.4\% area under rabi crops out of total area. So, the total percentage of area is 39.8 under fallow lands in rabi season after kharif rice harvesting and $17 \%$ area covered under rabi crops after kharif harvesting. $10.5 \%$ area is found to be suitable for short duration rabi crop (Figure 9). Khaira and Simulia blocks showing high percentage of suitability and Baliapal (2.1\%) and Bhograi (1.5\%) block are less suitable for rabi cropping system. (Figure 10).

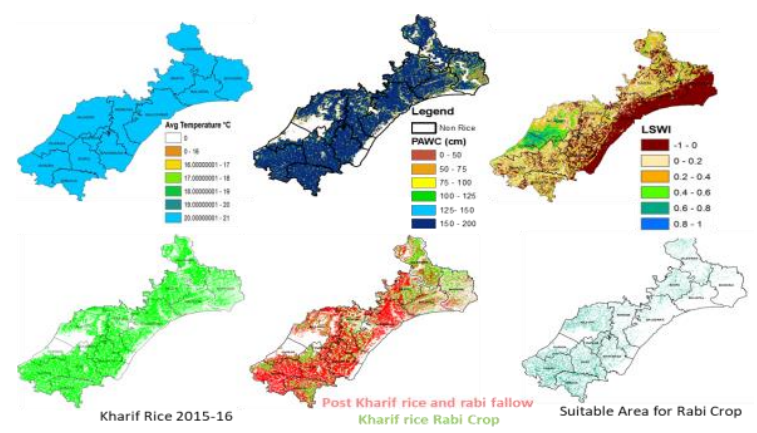

Figure 9. Kharif Rice, Rabi Fallow and Rabi suitable area for Balasore district of Odisha

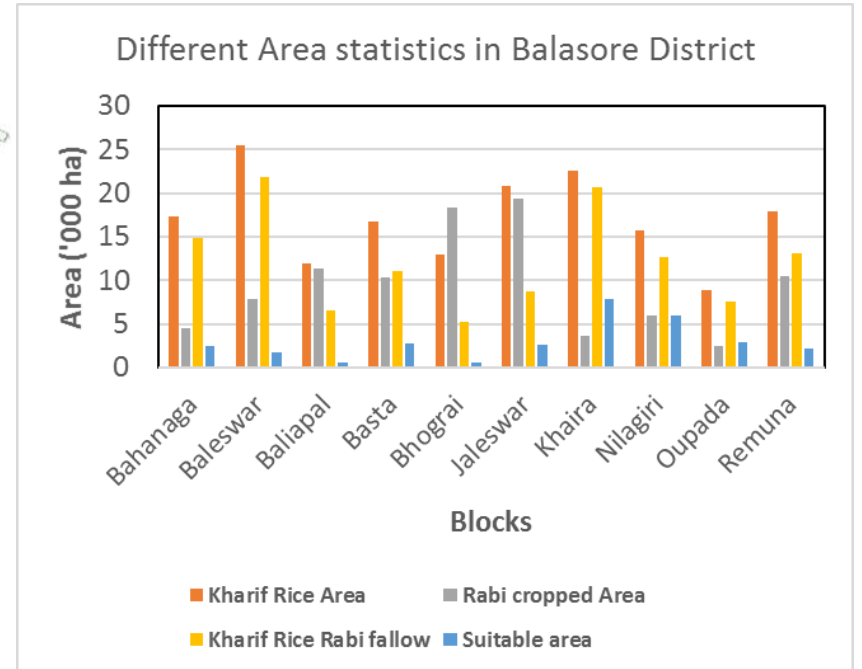

Figure 10. Block level Statistics of Balasore district of Odisha

\section{CONCLUSION \& FUTURE WORK}

The post kharif rice-rabi fallow area was assessed for suitability for short duration crops in four pilot districts, considering the climate and soil conditions. The kharif rice area in those districts ranged between $20-40 \%$ of the geographical area, while the suitable area was found to range between $8-13 \%$ of the geographical area. The study estimated the land suitability for pulses or short duration legumes that can be planted in fallow lands after kharif rice harvesting in study districts using remote sensing and GIS technology and field survey. Legumes can improve the soil health by fixing nitrogen into the soil which will benefit farmer by increasing rice productivity in next season. Thus, this exploratory study could show with remote sensing and other agro-physical parameters, it is possibly not only to map the rice -fallow area, but also to assess the suitability of growing other crops and hence improve the food security and farmer's income.

This study was a pilot, carried out at the request of Department of Agriculture, Cooperation and Farmers' Welfare (DAC\&FW) to show the utility of satellite data and geospatial technology for site suitability assessment of growing short duration pulses, during rabi season in post-Kharif rice fallow areas. Later on, the study was carried out, in detail, under a large project sanctioned by DAC\&FW, to NRSC and MNCFC, for site-suitability assessment of post kharif rice fallow areas of 6 East-Indian states, at block and village level.

\section{ACKNOWLEDGEMENTS}

Authors are grateful to Crops Division of the Department of Agriculture, Cooperation and Farmers' Welfare, for their keen interest in the study. Thanks are also due to the Director and Deputy Director (RS\&GISAA) of National Remote Sensing Centre for their strong support. Authors are thankful to the FASAL project at MNCFC for providing support in satellite data and algorithm for kharif rice mapping.

\section{REFERENCES}

Bandyopadhyay, K.K., Sahoo, R. N., Singh, R., Pradhan, S., Singh, S., Krishna, G., Pargal, S. and Mahapatra, S. K. Characterization and crop planning of rabi fallows using remote sensing and GIS. Current. Science. , 2015108 (11):2051-2062. 
Chandna, P., Hodson D.P, Singh U.P., Singh A.N., Gosain A.K., Sahoo R.N., and. Gupta R.K. "Increasing the Productivity of Underutilized Lands by Targeting Resource Conserving Technologies-A GIS/Remote Sensing Approach: A Case Study of Ballia District, Uttar Pradesh, in the Eastern Gangenic Plains. Mexico D.F.:CIMMYT, 2004.

Dabin, Z., Y. Pengwei, Z. Na, Y. Changwei, C. Weidong and G. Yajun. "Contribution of Green Manure Legumes to Nitrogen Dynamics in Traditional Winter Wheat Cropping System in the Loess Plateau of China." European Journal of Agronomy 2016. , 72: 47-55.

Dixon, J., A. M. Omwega, S. Friel, C. Burns, K. Donati, and R. Carlisle. "The Health Equity Dimensions of Urban Food Systems." Journal of Urban Health. 2007 , 84: 118-129

Ghosh, P., K. Bandyopadhyay, R. Wanjari, M. Manna, A. Misra, M. Mohanty, and A. S. Rao., "Legume Effect for Enhancing
Productivity and Nutrient Use-efficiency in Major Cropping Systems - An Indian Perspective: A Review." Journal of Sustainable Agriculture , 2007 30: 59-86

Gumma, M.K., Nelson, A, Thenkabail, P. S. and Singh, A. N. Mapping rice areas of South Asia using MODIS multitemporal data. J Appl. Rem Sens. 2011, Vol. 5.

Subbarao, G.V., Kumar Rao, J.V.D.K., Kumar,J., Johansen, C., Deb, U.K., Ahmed, I. , Krishna Rao, M.V., Venkatratnam, L., Hebbar, K.R., Sai, M.V.R.S. and Harris, D. Spatial distribution and quantification of rice -fallows in South Asia - potential for legumes. Patancheru, Andhra Pradesh, India: International Crops Research Institute for the Semi-Arid Tropics. 2001, pp 316.

USGS. 2016. Landsat 8 (L8) Data Users Handbook. LSDS1574. Version 2.0. Department of the Interior U.S. Geological Survey. 98. 